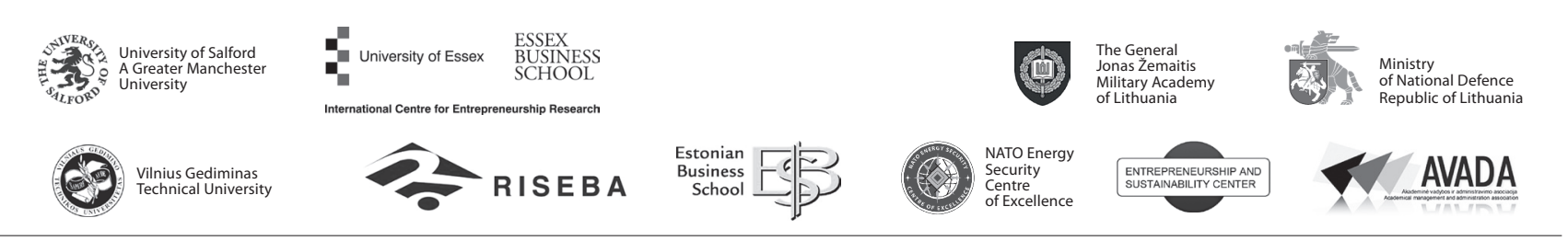

\author{
JOURNAL OF SECURITY AND SUSTAINABILITY ISSUES \\ ISSN 2029-7017 print/ISSN 2029-7025 online \\ 2018 March Volume 7 Number 3 \\ https://doi.org/10.9770/jssi.2018.7.3(6)
}

\title{
SECURITY IN CRISIS SITUATIONS: THE PROBLEMS OF THE LIMITS OF THE HUMAN RIGHTS
}

\author{
Birutė Pranevičiené $\dot{1}^{1}$ Violeta Vasiliauskiené⿱ \\ ${ }^{1,2}$ Mykolas Romeris University, Faculty of Public Security, \\ V. Putvinskio g. 70, Kaunas 44211, Lithuania \\ E-mails: ${ }^{1}$ praneviciene@mruni.eu; ${ }^{2}$ v.vasiliauskiene@mruni.eu
}

Received 26 March 2017; accepted 20 January 2018

\begin{abstract}
The article discusses the problems of the limitations of the human rights in the situations of crisis. The measures of crisis management are undertaken both in international and national levels, but the definitions of crisis and crisis management are rarely provided in legal acts. The article further discusses the theories of national security and their connection with the assurance of human rights. The permanent and temporary limitations of the human rights provided in international and national legal acts are discussed in the context of the measures taken in crisis management.
\end{abstract}

Keywords: crisis management, human rights, derogations of human rights, public emergency, migrant crisis.

Reference to this paper should be made as follows: Pranevičienè, B.; Vasiliauskienė, V. 2018. Security in crisis situations: the problems of the limits of the human rights, Journal of Security and Sustainability Issues 7(3): 439-448.

https://doi.org/10.9770/jssi.2018.7.3(6)

JEL Classifications: K14, K38, K49

\section{INTRODUCTION}

The migration flows to the European Union have tested in 2015 ,the concept of the management of the external borders of the European Union and demonstrated its failure in the field of common policy, common approach and solidarity between the Member States." (Pūraitè, Greičius, Seniutiené, 2017; Lincényi, 2017). In 2016, despite the decrease of detections of illegal border-crossing at the external borders, it still remains a very pressing issue both at the European level and for separate states. „A total of 511371 detections was reported by EU Member States in 2016, which represented a 72\% decrease compared with 1.8 million detections in 2015." (FRONTEX, 2017). Other crisis situations are for example, "heat wave in Europe causing 35000 deaths in 2003, cyber-attacks carried out against public administration institutions communication and information systems in Estonia in 2007, hybrid war in Ukraine in 2014, the attack of the Islamic radicals executed against the editorial office of French satirical weekly in 2015" (Survila et al., 2017), and other examples which illustrate that there is a real need for effective crisis management practice. Such situations amount to international multifaceted crisis and may require the states to resort to crisis management tools in order to ensure the safety and security of all the parties involved. On the other hand such measures may have the impact on the human rights of the inhabitants of such countries and of the migrants themselves. The question of the balance between national security demands and human rights obligations is not as evident especially when it seems that the needs of crisis management override the obligations set out in the human rights norms. The human rights treaties set 
out clear indications and conditions according to which certain derogations from human rights obligations are possible in public emergency situations.

The article therefore aims to provide the general framework on the definition of crisis and the regime of crisis management and its relationship with the human rights law. In order to achieve this aim, the authors will analyse the concept of national security, its main theories and its links with the concept of human rights. Furthermore, the permanent and temporary limitations of human rights are discussed in the context of crisis management.

\section{THE CRISIS MANAGEMENT AS PART OF NATIONAL SECURITY MEASURES}

\subsection{The legal definition of crisis}

The crisis in general can be defined as "an unstable or crucial time or state of affairs in which a decisive change is impending; especially: one with the distinct possibility of a highly undesirable outcome" (Definition of crisis), or as "an unstable situation of extreme danger or difficulty" (Crisis). NATO outlines that "a crisis can be political, military or humanitarian and can also arise from a natural disaster or as a consequence of technological disruptions." (NATO, 2015).

Lithuanian Government has adopted a conception for the future law on crisis management, proposing the main dispositions of the future law. As the legal definition of crisis is not yet established in the legal system of Lithuania, the Government proposes to define crisis as the situation, determined by the international or national event or process, which poses danger to national security and where the prevention of the possible consequences of which or the elimination of present consequences requires special measures. (Decree of the Lithuanian Government, 2001b). The document further defines crisis management as a coordinated activity of state institutions aimed at the elimination of the causes of crisis, at the reduction of the effect of crisis and restoration of the ordinary state of affairs.(Decree of the Lithuanian Government, 2001b). The definition of crisis is important as it is the ground for taking special measures and may in some cases, as it will be discussed below, constitute grounds for setting up limitations of the rights of individuals.

Therefore it could be summed up that a crisis is a situation where a danger to the security of the state or persons arises and the elimination of which requires special, extraordinary, particular measures.

\section{2. Crisis management in international level}

Crisis management is undertaken both in international and national levels. For example, crisis management is outlined in NATO Strategic Concept as one of the measures taken in order to enhance the security and stability of the Euro-Atlantic area. (NATO, 1999). NATO aims to "stand ready, case-by-case and by consensus, in conformity with Article 7 of the Washington Treaty, to contribute to effective conflict prevention and to engage actively in crisis management, including crisis response operations."(NATO, 1999). If the crisis situation happens, NATO seeks to contribute to its effective management, including the effectuation of non-Article 5 crisis response operations. (NATO, 1999).

United Nations include crisis management measures in their peacekeeping and military missions. United Nations have developed its Crisis Information Management Strategy, which is based on the recognition that governments, the UN, IFIs, non-governmental organisations, business and media have significant experience in crisis response, but the UN aims to coordinate information related to crises management - to produce, disseminate and archive information in a manner that can be scaled up or rapidly focused to deal with any type of crisis. (UN Crisis Information Management Strategy).

The Organisation for Security and Co-operation in Europe (hereinafter referred to as OSCE) sets out crisis management as one of the phases of the "conflict cycle". The Organisation addresses the conflicts and its approach includes crisis management in field operations and in the activities of Conflict Prevention Centre. 
(OCSE. Conflict prevention and resolution). This centre now "provides policy advice, support, and analysis to the Secretary General, Chairmanship, participating States, and field operations. It acts as an OSCE-wide early warning focal point, facilitates negotiation, mediation, and other conflict prevention and resolution efforts, and supports regional co-operation initiatives“"(OCSE. Conflict prevention and resolution).

\subsection{Crisis management system in Lithuania}

Speaking of Lithuania, crisis management is defined in Lithuanian Law on the Basics of National Security (1997) as being part of all measures of national security. In the Basics of National Security of Lithuania enshrined by the same law, it is established that „The principal long-term national programmes for the strengthening of national security shall be: development of the system of crisis management" (chapter 11). It is further established that ,the system of crisis management shall be created and developed to forecast and monitor the emergencies and critical phenomena posing danger, to prepare and implement preventive measures, to determine and manage crises and to respond thereto." (Chapter 14).

The institutions and structures taking part in the crisis prevention and management process in Lithuania are the Crisis Management Committee, consisting of the main ministers associated with crisis management. (Decree of the Lithuanian Government, 2001b). "Where necessary, the Crisis Management Committee shall, having regard to the nature of a crisis, take a decision on establishing the Joint Co-ordination Centre consisting of representatives of appropriate ministries and other state institutions for the co-ordination of crisis management and response." (Law on the Basics of National Security, 1997). Crisis prevention and preparedness for crisis management are co-ordinated by the Office of the Prime Minister. The Office of the Prime Minister co-ordinates the drafting of integral crisis and emergency prevention and management plans and measures; ministries and other state institutions prepare such plans and measures within the sphere of their competence providing for action co-ordination with other institutions. The Government approves integral plans of and measures for the management of crises and emergencies. (Law on the Basics of National Security, 1997).

Previously the institutional system of crisis management in Lithuania included also the Crisis management centre by the Ministry of Defence, which was established in 2001 (Decree of the Lithuanian Government, 2001a). The aims of the Centre activity were to carry out complex observation of possible risk factors, to foresee possible crises; to coordinate the activity of State institutions in the field of crises' prevention; to ensure effective infrastructure of crisis management; to ensure constant exchange of information about crisis management between different institutions; to develop international cooperation in this field (Decree of the Lithuanian Government, 2001a). But this institution was dissolved in 2010 (Decree of the Lithuanian Government, 2010), according to the conception of the crisis management system in the Republic of Lithuania (Decree of the Lithuanian Government, 2000). The question now arises whether such or similar institution is needed nowadays, having regard to present day realities.

The Lithuanian Government has a proposition to establish crisis operation centre in its conception for the future law on crisis management (Decree of the Lithuanian Government, 2012). It would be composed of the representatives of state institutions and would execute the decisions of the Government of Lithuanian Republic, organize the elimination of crises' consequences. The leader of the crisis operation centre would be designated by the Prime Minister (Decree of the Lithuanian Government, 2012).

The need of such committee was illustrated by an incident in May 2015, when an airplane "AN-2" with two pilots was declared missing above the Baltic Sea. The search of the airplane took three days, it was found in the sea ground with the body of one pilot. As of now, the coordination of such events, such crises is entrusted to different state institutions, such as military and other, and the execution of the search operation was criticized as having been not as successful as possible and raised talks about the single institution for the coordination of crisis situations. 


\subsection{The concept of national security and its relationship with human rights}

As it has been mentioned above, crisis management is an integral part of national security. Security is defined as one of the main needs of a person. A need is something that is necessary for a person to ensure his or her existence (Greičius, Pranevičienè, 2010). Security is defined in objective sense by the absence "of any threat to the valuables possessed, and in the subjective sense - the absence of fear that these valuables will be attacked." (Wolfers, 1962). Therefore the main question is the object of security, or in other words, whose security is it. Two main objects may be distinguished - that is the state and the individual need is something that is necessary for a person to ensure his or her existence (Greičius, Pranevičienè, 2010). Consequently, there are two main theories of security - traditional state oriented concept of security and human security theory.

The first view of security - traditional policy of security is based on the idea that all the members of society or individual interests are subordinate to the interest of the state. The main aim is to protect the state from the threat of military aggression, to ensure the territorial integrity of the state (Pranevičiene, 2011). Creation of the strategies aimed at security is usually concentrated in the hands of state institutions, and the implementation of these strategies rarely involves the society (Pranevičienè, 2011).

The problem with this theory lies in the fact that a secure state does not necessarily mean secure citizens. It is important to secure citizens from foreign military aggression but this action is not a sufficient condition guaranteeing the security of citizens. Furthermore, the state-oriented security conception results in actions of states augmenting their military capacities and therefore they increase their security at the expense of the security of other states. Therefore the Organization for Security and Co-operation in Europe started to formulate the conception of security in the following terms - to establish state commitments not to increase their security at the expense of the security of other states. (Helsinki Final Act, 1975).

Having regard to the shortcomings of the abovementioned view of national security, another theory of security oriented towards the person in the first place and only then towards the security of the whole state provides some answers to the problems associated with state-oriented security conception. The conception of "human security" is relatively new but is gaining acceptance. It is used to outline complex inter-related threats to contemporary society and its members (Greičius, Pranevičienè, 2010). It is not easy to define the concept of "human security". On one hand, this aim to protect security of a person is closely related to collective aims of the society as a whole, seeking to protect both the state and every individual comprising the state. On the other hand, the state, being a power in a particular territory, may pose risk to individual's security.

One of the definitions of human security is provided by Caroline Thomas, who states, that the approach to security "should prioritize the security of the individual and that security is achieved only when basic material needs are met and meaningful participation in the life of the community and human dignity are realized (Bellamy, McDonald, 2002). A similar definition was proposed in the 1994 United Nations Human Development Report which outlines human security as "safety from chronic threats such as hunger, disease and repression and protection from sudden and harmful disruptions in the patterns of daily life." (Human Development Report 1994, 1994).

"Over the last few decades it has been accepted that subjective and objective level of security depends on the level of implementation and protection of human rights." (Pranevičiené, 2011). Individuals choose in different situations interests that are more important and may sacrifice those that are less important to them. Such processes are related to processes of human socialization, individual experience, conditional reflexes (stereotypes), results of education of social communities, social control, etc. (Pranevičienè, 2011). Individuals are forced to choose greater values, by way of agreeing to renounce certain things having less impact on their existence, in the name of securing the great values. Some scientists refer to those greatest values as natural human rights, such as the right to life, the right to property, the right to privacy, immunity right, etc. (Pranevičienè, 2011). The state and society may be considered the safe guarders of those rights, but on the other hand, they may be the biggest threats to those rights. The rights of one person and their implementation may pose great risk to the rights of others. 
In the context of national security and of crisis management, two spheres conflict - that is the sphere of human rights and the sphere of the state which should protect the first, but has the ability to abuse the rights of persons in its jurisdiction. (Greičius, Pranevičienè, 2010). The state and its institutional system is not only a possible defender of human rights - as their implementation requires the powers of the state - but also potentially dangerous adversary, therefore its power should be constrained by national constitutions and laws. The same principle applies not only to peaceful situations, but also to situations of crisis, requiring special measures that might infringe the abovementioned values - that is, the rights of individuals. I

\section{THE LIMITATIONS OF HUMAN RIGHTS IN THE CONTEXT OF NATIONAL SECURITY}

Human rights have become a universal virtue, and their protection is of high importance in every state. Twentieth century marks an important milestone in the history of human rights as it is the age when human rights were firstly and universally enshrined in international documents. Before the 1948 Universal Declaration on Human Rights, adopted by the United Nations General Assembly, there were only a few international treaties that were in any way connected to the concept of human rights, as it was more a matter of internal national law. But after the Second World War and the establishment of United Nations, the concept started to develop rapidly. Only after two years after the abovementioned Declaration, European states united and created Council of Europe and adopted Convention for the Protection of Human Rights and Fundamental Freedoms in 1950, and the European Social Charter in 1961. On universal level contractual obligations were created by the signing of two covenants in 1966 - International Covenant on Civil and Political Rights (hereinafter - ICCPR) and the International Covenant on Economic, Social and Cultural Rights under the auspices of United Nations.

\subsection{The concept of the limits on human rights}

The international documents on human rights foresee situations where the imposition of limits to the rights of an individual may be set out. They could be distinguished as permanent and temporary limitations.

The permanent limitations of a particular right are set out in the same provisions regulating the content of a particular right. If one would take the example of the right to privacy as it is set out in the European Convention for the Protection of Human Rights and Fundamental Freedoms (hereinafter - ECHR). For example, the right to liberty may be limited in the instances enumerated in Article 5 (1) of ECHR, that is, in the case of the lawful detention of a person after conviction by a competent court; the lawful arrest or detention of a person for noncompliance with the lawful order of a court or in order to secure the fulfilment of any obligation prescribed by law; the lawful arrest or detention of a person effected for the purpose of bringing him before the competent legal authority on reasonable suspicion of having committed an offence or when it is reasonably considered necessary to prevent his committing an offence or fleeing after having done so; the detention of a minor by lawful order for the purpose of educational supervision or his lawful detention for the purpose of bringing him before the competent legal authority; etc. (European Convention on Human Rights, 1950, Article 5 (1)). The right to freedom of peaceful assembly and to freedom of association may be restricted if "prescribed by law and are necessary in a democratic society in the interests of national security or public safety, for the prevention of disorder or crime, for the protection of health or morals or for the protection of the rights and freedoms of others." (European Convention of Human Rights, 1950, Article 11(2)). As the rights of individuals are always related to the rights of other individuals and to the interests of the society as a whole, there are instances where the limitations of such rights are possible, but on the condition that, firstly, they are prescribed by law, secondly, they are necessary for the attainment of the objective listed and are proportionate to aims sought. Therefore if the measures limiting the scope of human rights fulfil those conditions they may be used in crisis situations to address possible danger.

\subsection{Temporary limitations of human rights in case of public emergency situation}

Temporary limitations of human rights are possible in times of emergency. Besides the limitations set out in the particular descriptions of treaties, human rights treaties have established a system of derogations allowing "states parties to adjust their obligations temporarily under the treaty in exceptional circumstances, i.e. in times of public emergency threatening the life of nation. Examples of emergency situation include, but are not limited 
to, armed conflicts, civil and violent unrest, environmental and natural disasters, etc." (Derogation from human rights treaties in situations of emergency). For example, Article 15 of ECHR (1950) provides that "In time of war or other public emergency threatening the life of the nation any High Contracting Party may take measures derogating from its obligations under this Convention to the extent strictly required by the exigencies of the situation, provided that such measures are not inconsistent with its other obligations under international law." ICCPR (1966) repeats the possibility of derogation word per word and adds that such measures may "not involve discrimination solely on the ground of race, colour, sex, language, religion or social origin."

ECHR (1950) further stipulates that "[n]o derogation from Article 2, except in respect of deaths resulting from lawful acts of war, or from Articles 3, 4 (paragraph 1) and 7 shall be made under this provision." This provision lists rights that are non-derogable in any emergency situation. That means that right to life, prohibition of torture, prohibition of slavery and forced labour, and right not to be punished retroactively may be infringed only on the grounds stated out in the articles regulating the content of such rights, no further infringements or limits may be set on the execution of such rights. ICCPR (1966) lists the same non-derogable rights and adds that the right not to be imprisoned for inability to fulfil contractual obligations, the right to be recognized as a person before the law and the right of freedom of thought, conscience and religion are also non-derogable.

The procedure of reporting is also established in the same article of ECHR. It indicates that "Any High Contracting Party availing itself of this right of derogation shall keep the Secretary General of the Council of Europe fully informed of the measures which it has taken and the reasons therefor. It shall also inform the Secretary General of the Council of Europe when such measures have ceased to operate and the provisions of the Convention are again being fully executed." Similar provisions are contained in Article 4 of ICCPR.

"The derogation articles embody an uneasy compromise between the protection of individual rights and the protection of national needs in times of crisis" (Hartman, 1981). There are two essential standards for a valid derogation: first, the existence of public emergency threatening the life of the state, and secondly, the measures taken - that is, the measures limiting human rights provided for in the human rights treaties - are strictly required by the exigencies of the situation. (Hartman, 1981). The question arises whether all crisis situations as analyzed in the present writing may qualify as public emergencies threatening the life of the state, as only in such case crisis management actions could limit human rights. As the definition of "public emergency" is not provided for in the abovementioned treaties, it is due to the jurisprudence of human rights bodies to define what situations qualify as such.

United Nations Human Rights Committee (hereinafter - HRC) which foresees the implementation of ICCPR and tries petitions submitted by the citizens of states having ratified the Additional Protocol of ICCPR, as noted that "not every disturbance or catastrophe qualifies as a public emergency which threatens the life of the nation". (Derogation from human rights treaties in situations of emergency). The ICCPR does not make reference to war, yet "civil war and other cases of serious, violent international unrest are by for the reasons most asserted for declaring a state of emergency" (Nowak, 2005).

European Court of Human Rights (hereinafter referred to as ECtHR) has qualified in Lawless v. Ireland public emergency as "an exceptional situation of crisis or emergency which afflicts the whole population and constitutes a threat to the organised life of the community of which the community is composed". (European Court of Human Rights, 1961). ECtHR developed the elements of the definition of 'public emergency' in its later socalled Greek case, where it pronounced that "public emergency", firstly, must be actual or imminent, secondly, the effects of the emergency must involve the whole nation, thirdly, there is a threat to the continuance of the organized life of the community, fourthly, the crisis or danger must be exceptional, and therefore normal regular measures or restrictions, permitted by the ECHR as permanent possibilities to limit human rights in order to attain public safety, health and order, are not sufficient to address such a threat (Derogation from human rights treaties in situations of emergency). In the 2009 judgment in the case of A. and others v. UK ECtHR agreed that, for example, $9 / 11$ attacks on the United States and the threat resulting thereof constituted an emergency in the sense of Article 15 of ECHR (European Court of Human Rights, 2009). It could be deduced that the recent terrorist attacks in France, Paris, in November 2015, where over 130 persons were killed in several separate, but 
coordinated terrorist acts, could also constitute such situation in the sense of convention. The degree of "margin of appreciation" varies depending on the body deciding the case - whereas the ECtHR has stated that states have discretion while deciding whether the state of "public emergency" exists, albeit "accompanied by European supervision", HRC was far stricter and stated that States Parties are under a duty to give a detailed account of the relevant facts containing the "public emergency", and the Committee evaluates the situation at hand (Derogation from human rights treaties in situations of emergency).

Therefore it is hard to state whether all crises may rise to the standards set out above. As crisis is not widely described in any international legal documents, it is hard to draw the line between the public emergency and crisis situation. It could be proposed that as the term "crisis management" is quite often used, it would be important to draw a legal definition of crisis both in international and national levels, thus enabling the institutions to distinguish whether the temporary derogations from human rights are possible (in the situations of threat posing danger to the whole nation, having exceptional circumstances), or whether the institutions may only rely on the derogations set out as permanent derogations applied in "normal" times. Thus the proposed legal regulation in Lithuania which provides the definition of crisis and the promulgation of crisis is very commendable, as it provides the situation with more legal certainty. The measures that the institutions may take could also be described in the proposed legal regulation, if it is possible to define them in general terms.

Other requirements for the application of rules of "public emergency" are the requirements of proclamation and notification. The proclamation means the declaration of a particular situation as crisis. It does not necessarily mean that there will be derogations from human rights obligations. Therefore when the situation of crisis declared "public emergency" requires certain derogations and limitations of human rights, the duty of notification arises and means that those measures foreseen have to be reported to the human rights bodies. Regarding Lithuania, it is important to designate a particular institution of body of crisis management responsible for the decision to declare public emergency in the sense of ECHR and the provision of information regarding such situation to the ECtHR and HRC.

The measures taken in response to limiting human rights must be limited "to the extent strictly required by the exigencies of the situation" (European Convention on Human Rights, 1950, Article 15(1)) - that is, they need to be proportionate. The HRC stresses three important factors while assessing proportionality of particular measures: severity, duration and geographic scope, and also states that restrictions that are already allowed with the treaty provisions on certain freedoms, for example, the freedom of movement or freedom of assembly are "generally sufficient" to cover situations of "mass demonstrations including instances of violence or a major industrial accident." (Derogation from human rights treaties in situations of emergency). The HRC requires the states to provide careful justification not only for their decision to proclaim a state of emergency, but also for any specific measures undertaken in a particular situation. By contrast, the ECtHR allows its Member States a wide margin of appreciation "how far it is necessary to go in attempting to overcome emergency" (European Court of Human Rights, 1978).

The example of actions taken in Paris, France and in Brussels, Belgium could be an illustration of such situation. In the aftermath of the attack France declared the state of emergency and extended the validity of such declaration for three months. Large public gatherings, including protests, were banned under the emergency powers. "During the first three days after emergency law was put into effect, 414 homes were searched, 29 people were arrested and 118 were placed under house arrest, according to a Ministry of Interior press release published on Wednesday." (Safdar, Strickland, 2015). Later it was counted that 1,072 searches were conducted, 139 police interogations have taken place, 117 people were detained and 253 people were placed under house arrest. (Nordwall, 2015). Under the emergency powers, the government is able „to impose house arrest without authorization from a judge, conduct searches without a judicial warrant, seize any computer files it finds, and block websites deemed to glorify terrorism without prior judicial authorization." (Nordwall, 2015). Therefore the question of the limitation of the rights to liberty, freedom of movement, freedoms of association and expression comes into question. The French government and its institutions should consider which measures are necessary for crisis management aims and should clearly evaluate the measures taken at the first possibility. Remembering the notion of human security, the state may be the main protector of human rights but also the main source of 
danger. It is important not to create more insecurity by the excessive acts of the state institutions.

Therefore in the situations of crisis the state institutions proclaiming the state of emergency and taking up crisis management action should carefully deliberate whether the restrictions on human rights are necessary for the purposes of tackling the crisis at hand. Firstly, as it has been mentioned, it is important that the legal term of "crisis" were established in the legal acts as far as it is possible to define it. Secondly, the institutions taking part in crisis management and their functions should be stated clearly in state legislation. Taking the example of Lithuania, in author's opinion, the powers are defined only in the abstract but more precision is needed. This is also necessary in order to have the procedures that entail the possibility of limiting human rights set out clearly in laws.

Furthermore, if the need of the limitations or derogations from human rights arises, the state institutions should firstly consider whether the limitations provided for in the specific articles concerning particular rights, so called permanent limitations could help achieving the aims of crisis management. Only after this evaluation, if the situation so requires, the state institutions should carefully evaluate further restrictions on human rights on the grounds of public emergency as provided for in the human rights treaties.

\section{Conclusions}

The term "crisis" is defined only in a few international documents, the definition of crisis is not yet provided also in Lithuanian legal regulation. On the other hand the concept of "crisis management" is a more widely used term, but also not widely defined. Therefore it is important to draw a legal definition of the terms "crisis" and "crisis management".

The problem with the view of security as being security of the state lies in the fact that a secure state does not necessarily mean secure citizens. This shortcoming can be solved shifting the focus of security from the state towards the person in the state. The measures taken in the field of national security have to address not only the threat or occurrence of armed attacks on the state but also other matters that concern the safety and security of every individual in the society. Those measures firstly are related to the fulfilment of human rights. The state in the field of security may be considered the main guarantor of the rights of the individuals, but also it possesses tools to infringe human rights through its actions, therefore utmost attention has to be paid to strict adherence to human rights treaties even in the situations of crisis.

The necessities of life in a society and especially in times of crises may lead to situations where some limitations on the human rights set out in international treaties and national laws are inevitable. The European Convention on Human Rights and International Covenant for Civil and Political Rights both foresee the possibility of such limitations. The first sort of limitations are set out in the articles spelling out the rights themselves and are more related to the peaceful times and ordinary needs of the society. These could also be applied during "mild" crises. But when the situation is one of public emergency and threatens the life of the whole nation, there are special provisions allowing for temporary derogations from human rights.

In order to provide legal certainty and legal grounds for such limitations and prevent abuse it is important that the term "crisis" were defined in legal acts of the state and also in international legal practice. The legal acts should also clearly state the responsibilities and powers of the institutions related to crisis management.

Furthermore, if the need of the limitations or derogations from human rights arises, the state institutions should firstly consider whether the limitations provided for in the specific articles concerning particular rights, so called permanent limitations could help achieving the aims of crisis management. Only after this evaluation, if the situation so requires, the state institutions should carefully evaluate further restrictions on human rights on the grounds of public emergency as provided for in the human rights treaties. 


\section{References}

Bellamy, A.J., McDonald, M. 2002 'The Utility of Human Security’: Which Humans? What Security? A Reply to Thomas \& Tow. Security Dialogue September 33: 373-377.

Council of Europe, 1950. European Convention for the Protection of Human Rights and Fundamental Freedoms, as amended by Protocols Nos. 11 and 14, ETS 5.

Council of Europe, 1996. European Social Charter (Revised), ETS 163.

Crisis. [accessed 2015-11-26], <http://www.vocabulary.com/dictionary/crisis>

Decree of the Lithuanian Government, 2000, No. 1365 "Regarding the Approval of Measures of Execution of the Conception of the Crises Management System of Lithuanian Republic", Official Gazette, 2000, No. 98-3104.

Decree of the Lithuanian Government, 2001a, No. 939, "Regarding the Establishment of the Crisis Management Centre under the Ministry of National Defence and the Authorisation of the Regulations of the Centre". Official Gazette, 2001, No. 66-2416.

Decree of the Lithuanian Government, 2001b. No. 1427 "Regarding the Composition and Regulations of the Crisis Management Committee". Official Gazette, 2001, No. 101-3605.

Decree of the Lithuanian Government, 2010, No 145 „Regarding the Liquidation of the Crisis Management Centre under the Ministry of National Defence and the Abolishment of Certain Decrees of the Government of Lithuanian Republic". Official Gazette, 2010, No. 21-987.

Decree of the Lithuanian Government, 2012, No. 63 "Regarding the Approval of the Conception of the Lithuanian Republic Law on Crisis Management”, Official Gazette, 2012, No. 64-3245.

Definition of Crisis, Merriam-Webster Dictionary, [accessed 2015-11-26], <http://www.merriam-webster.com/dictionary/crisis>.

Derogation from human rights treaties in situations of emergency. RULAC Rule of Law in Armed Conflicts Project. [accessed 2015-11-24] http://www.geneva-academy.ch/RULAC/derogation_from_human_rights_treaties_in_situations_of_emergency.php

European Court of Human Rights, 1961. Lawless v Ireland (No 3) Application No. 332/57. 1 EHRR 15.

European Court of Human Rights, 2009. A and Others v. United Kingdom, Application no. 3455/05. 1 EHRR 222.

European Court of Human Rights. 1978. Ireland v United Kingdom, Application No. 5310/71. EHRR, Series A No 35.

FRONTEX, 2017. Risk Analysis for 2017. [accessed 2017-09-12]. http://frontex.europa.eu/assets/Publications/Risk_Analysis/Annual_ Risk Analysis 2017.pdf

Greičius, S. Pranevičienė, B. 2010. Asmens ir valstybès saugumo samprata, užtikrinimo poreikis ir problemos. [The Concept of Personal and State Security, the Need to Ensure and Its Problems] In: Monografija "Regnum Est. 1990 m. kovo 11-osios Nepriklausomybes Aktui - 20. Liber Amicorum Vytautui Landsbergiui.” Vilnius, Mykolo Romerio Universitetas: 719-739.

Hartman, J. F., 1981. Derogation from Human Rights Treaties in Public Emergencies--A Critique of Implementation by the European Commission and Court of Human Rights and the Human Rights Committee of the United Nations. 22 Harvard International Law Journal: 1-52.

Helsinki Final Act, 1975. Conference on Security and Co-operation in Europe. [accessed 2015-11-26]. <https://www.osce.org/ $\mathrm{mc} / 39501$ ? download $=$ true $>$.

Human Development Report 1994. United Nations Development Programme. New York, Oxford University Press, 1994.

Lithuanian Republic Law on the Basics of National Security, 1997. Official Gazette, 1997, No. 2-16.

Lincényi, M. 2017. Entrepreneurship ecosystem facets: the European migrant crisis and public opinion in Slovakia, Entrepreneurship and Sustainability Issues 5(2): 357-367. https://doi.org/10.9770/jesi.2017.5.2(14)

Messari, N. 2002. The State and Dilemmas of Security: the Middle East and the Balkans, Security Dialogue, SAGE publications, Vol. 33(4).

NATO, 1999. The Alliance's Strategic Concept, Approved by the Heads of State and Government participating in the meeting of the North Atlantic Council in Washington D.C. 24 Apr. 1999. [accessed 2015-11-26] <http://www.nato.int/cps/en/natohq/official_ texts_27433.htm?selectedLocale $=$ en $>$ 
NATO, 2015. Crisis management, 29 January. [accessed 2015-11-26], <http://www.nato.int/cps/en/natolive/topics_49192.htm>.

Nordwall, S. 2015. HRW Urges France to Remain Mindful of Human Rights. Voice of America. 24 November. [accessed 2015-11-25]. $<$ http://www.voanews.com/content/human-rights-watch-france-paris-attacks/3072318.html>.

Nowak, M. 2005. UN Covenant on Civil and Political Rights. CCPR Commentary (2nd rev. ed.). Kehl am Rhein: Engel.

Organization for Co-operation and Security in Europe. Conflict prevention and resolution. [accessed 2015-11-24] <http://www.osce. org/secretariat/conflict-prevention>

Pranevičienè, B. 2011. Limiting of the Right to Privacy in the Context of Protection of National Security. Jurisprudence, 18(4): 16091622.

Pūraitè, A., Greičius, S., Seniutienè, D. 2017. Managing State Border in the Context of Migration Crisis in Europe: Lithuanian Case. Montenegrin Journal of Economics. Vol. 13, No. 3: 31-42.

Safdar, A. Strickland P. 2015. Mass raids after Paris attacks spark civil rights fears. Aljazeera, 22 November. [accessed 2015-11-25]. <http://www.aljazeera.com/news/2015/11/mass-raids-paris-attacks-civil-liberties-151122152222341.html>

Survila, A., Rakšnys, A.V., Tvaronavičienè, A., Vainiutė, M., 2016. Systemic Changes in Disaster Management in the Context of Public Sector Modernization. Journal of Security and Sustainability Issues, September, Vol. 6. No. 1: 37-52.

UN Crisis Information Management Strategy, United Nations. [accessed 2015-11-24] < http://ict4peace.org/the-crisis-information-management-strategy/\#sthash.ZURmz4MN.dpu >

UN General Assembly, 1966. International Covenant on Civil and Political Rights, 16 December, United Nations, Treaty Series, vol. 999, p. 171.

UN General Assembly, 1966. International Covenant on Economic, Social and Cultural Rights, 16 December, United Nations, Treaty Series, vol. 993, p. 3.

United Nations General Assembly, 1948. The Universal Declaration of Human Rights, Resolution No. 217A, 10 December 1948.

Wolfers, A., 1962. Discord and Collaboration, Baltimore: John Hopkins University Press.

Birutė PRANEVIČIENĖ is a Professor at Mykolas Romeris University, Faculty of Public security, Department of Law. She is also Head of Department of Law. She teaches and convenes Modules of international master programme organized by FRONTEX, European Joint Master in Strategic Border Management. Research interests: administrative law, constitutional law, human rights, environmental law.

Violeta VASILIAUSKIENE், lecturer at Public Security Faculty of Mykolas Romeris University in Kaunas, Lithuania. She teaches the subjects of International Public Law and European Union Law, is also actively involved in international study projects. Key areas of expertise:European Law, Use of Armed Force, Fight against Terrorism in International Law, Human Rights Law. 